\title{
Desalination of Hypersaline Brines with Joule-Heating and Chemical Pre- treatment: Conceptual Design and Economics
}

Dora E. Lopez $^{\text {a, } 1}$, Jason P. Trembly ${ }^{\text {a, b, } 2}$

${ }^{a}$ Institute for Sustainable Energy and the Environment (ISEE), Ohio University, $350 \mathrm{~W}$ State St, Athens, OH, 45701, USA

${ }^{\mathrm{b}}$ Department of Mechanical Engineering, Stocker Center 265, Ohio University, Athens, OH, 45701, USA

${ }^{1}$ lopezd3@ohio.edu, doracamponuevo@gmail.com

2 trembly@ohio.edu 


\begin{abstract}
Conventional seawater desalination technologies and fossil energy operations produce large volumes of hypersaline brines requiring proper management. Zero liquid discharge desalination processes can offer an economic and environmentally responsible method to manage these complex streams. The objective of this study was to assess preliminary economics for a novel Joule-heated desalination process design. Aspen Plus ${ }^{\circledR}$ was employed to model two scenarios, one with a eonventional chemical precipitation pretreatment using sodium sulfate, sodium hydroxide and calcium carbonate (Scenario A) and the other using $\mathrm{CO}_{2}$ instead of calcium carbonate as precipitating agent in the pretreatment stage (Scenario B). The conditions for the water desalination step were 22.1 MPa and $430{ }^{\circ} \mathrm{C}$. Internal Joule-heating provides the energy in the supercritical water separation step. The preliminary economic model projects a cost of $\$ 4.29$ per $\mathrm{m}^{3}$ feed $\left(\$ 0.68 / \mathrm{bbl}\right.$ feed) for Scenario A and $\$ 7.81$ per $\mathrm{m}^{3}$ feed $(\$ 1.24 / \mathrm{bbl}$ feed $)$ for scenario B.
\end{abstract}

keywords: Joule heating, hypersaline brine, produced water, Aspen Plus® Simulation, $\mathrm{CO}_{2}$ mineralization, techno-economics. 


\section{Introduction}

The water desalination industry experienced exponential growth through 2010 in response to increased global fresh water demand [1]. Over the past six years, there has been a sharp decline in worldwide contracted desalination capacity, resulting from the lingering effects of the 2008 economic downturn. However, this contracted capacity is expected to increase as the global population increases at a projected rate of 80 million people per year. The UN Water Coordination Mechanism predicts freshwater demand will increase to more than 60 billion $\mathrm{m}^{3}$ per year. With only $3.5 \%$ of global water resources being freshwater, research is currently focused on making desalination processes less energy intensive with greater costcompetitiveness and sustainability.

In general, natural or produced saline water sources can present different levels of salinity. Brackish water refers to a water that has a higher salinity than freshwater but lower salinity than seawater. The standard ocean seawater salinity is $3.5 \mathrm{wt}$. \% (35 g of salt per liter). Hypersaline water sources have salt concentrations that surpasses that of seawater (> 3.5 wt. \%).

Today, there is an increasing demand for desalination of man-made sources of hypersaline waters. For example, in seawater desalination, conventional water recovery plants produce vast amounts of hypersaline water globally [1]. Giwa et al. recently reviewed technologies for managing reject brine and highlighted the need for minimization and reuse of these streams by recovering value-added chemicals such as salts and metals [2]. Another example is hydraulic fracturing. In the U.S. alone, it is estimated that from 2008 to 2014, 930 million cubic meters of water were employed in hydraulic fracturing operations [3] resulting in nearly an equivalent volume of flowback and produced impaired waters requiring management. Other energy-related operations, such as geological $\mathrm{CO}_{2}$ sequestration, may also produce large amounts of extracted hypersaline water streams over an extended period of time [4-6].

Some hypersaline wastewater streams can be disposed back into the ocean, recycled or injected into local underground wells. However, when these options are not viable, a less favorable option is the disposal of the saline wastewater in publicly owned treatment works (POTWs). However, POTWs are not designed for wastewater desalination or removal of certain trace heavy metals, resulting in their discharge to the local watershed [7]. In the U.S., the EPA under the Clean Water Act (CWA), establishes regulation for the disposal of wastewaters in POTWs to 
prevent discharge of pollutants, with many states banning this practice altogether. Therefore, as a result of the combination of more restricted regulations and disposal costs (e.g., wastewater transportation and industrial wastewater treatment fees) and the demands of the water markets, the exploration of in situ desalination treatment alternatives has become more attractive.

In terms of final product form, desalination processes can be broadly divided into two main categories: water recovery (WR) processes, and zero liquid discharge (ZLD) processes. WR processes are the least expensive and most common approach to desalination. Some examples of this type of desalination processes are mechanical vapor compression (MVC) [8,9] and reverse osmosis (RO) $[10,11]$. These methods produce a treated water stream and a concentrated typically hypersaline - brine product. In contrast, ZLD processes produce a treated water stream and a solid mineral product.

The economics of desalination for both WR and ZLD processes are normally governed by energy costs. In an effort to reduce both the cost and the carbon footprint in desalination, many researchers are currently exploring renewable energy as the source of thermal and electric power in the process $[12,13]$. Solar desalination may offer an advantage in regions with high solar irradiation [14]. Caldera and co-workers recently reported the cost for desalination of seawater via RO membranes using electricity from solar and wind energy to be $0.59 € / \mathrm{m}^{3}-2.81 € / \mathrm{m}^{3}$ [15]. This cost range, about $\$ 0.1 / \mathrm{bbl} \$ 0.5 / \mathrm{bbl}$, is cost competitive for a WR process and low compared to ZID processes becattse the concentrated retentate stream is not treated.

Regardless of the source of the energy employed in the desalination system, a universal goal in desalination is to minimize process energy requirement. Thiel and coworkers recently compared the energy consumption for various WR desalination systems treating high salinity feedstock [16]. Here, the final concentrated brine product had a constant salinity of $26 \%$ (which is the $\mathrm{NaCl}$-water saturation limit at normal conditions). Using the second law of efficiency as a metric the ratio of the least amount of -work required for separation of the concentrated brine and the water product to the system exergy input the athors concluded that evaporative systems operated more efficiently than RO membranes at higher feed salinities due to their lower energy sensitivity to salinity.

While water recovery processes have been extensively studied, there are very few studies dealing with ZLD processes [17, 18]. Morillo et al. recently reviewed a number of WR and ZLD 
technologies and concluded ZLD processes incur very high desalination costs [19]. Little is known about the cost of supercritical water (SCW) desalination which is an emerging technology based on the changing polarity of water under supercritical conditions. Inorganic salts are separated from less polar water as a result of reduced solubility [20]. Therefore, the main water/salt separation occurs at supercritical conditions leaving no concentrated liquid stream behind. The challenge of the SCW-ZLD process is the corrosive environment - due to high chloride concentrations - and energy requirements.

To the best of our knowledge, there is no peer-reviewed literature available on conceptual economics of the SCW-ZLD desalination processes. In this study, we present an initial estimate for the economic feasibility of a SCW-ZLD desalination process that employs internal Joule heating. This methodology allows the desalination process to utilize fossil and/or renewable electrical power, when low-cost power is available at off-peak time periods. Two pretreatment cases were considered, one using eonventional chemical (sodium sulfate, sodium hydroxide and sodium carbonate) precipitation pretreatment and the other utilizing $\mathrm{CO}_{2}$ as softening agent in the brine pretreatment stage instead of sodium carbonate. This study also provides for the first time a model in Aspen Plus ${ }^{\circledR}$ for the SCW-ZLD desalination including salts.

\section{Conceptual Process Design and Economic Assessment}

\subsection{Conceptual Process Design}

A hypersaline brine feedstock may contain significant amounts of suspended and/or dissolved inorganic and organic contaminants. In order to treat these impaired water streams, a multi-stage desalination concept with ZLD was developed in this study. The desalination pathway can be divided into three main processing areas: 1) primary water treatment, 2) chemical softening, and 3) supercritical water salt separation. A brine flow rate of $113.6 \mathrm{~m}^{3}$ per hour (500 GPM) at $25^{\circ} \mathrm{C}$ and $0.1 \mathrm{MPa}(1 \mathrm{bar})$ was selected as the input basis for the design.

In primary treatment, suspended solids are usually separated by sock-filtration or sedimentation. Also at this stage, insoluble organic substances, such as free and emulsified oils are typically separated from water by employing membranes [21], hydro-cyclones or centrifuges. The 
treatment for microbial contamination was also considered part of this first area. Commercial UV light treatment has been shown to effectively deactivate bacterial DNA. Therefore, the filtered brine is treated with UV light before chemical treatment, where $99.9 \%$ of the bacterial contamination is assumed to be removed.

After the separation of suspended contaminants from the brine in the primary treatment stage, softening can be used to reduce the amount of total dissolved solids (TDS). The ions usually present in hypersaline water streams are monovalent cation $\mathrm{Na}^{+}$, alkali earth metal cations $\mathrm{Ca}^{2+}$, $\mathrm{Ba}^{2+}, \mathrm{Mg}^{2+}$ and $\mathrm{Sr}^{2+}$, and anions, $\mathrm{Cl}^{-}$and $\mathrm{SO}_{4}{ }^{2-}$. Other ions typically present in minor proportions include, $\mathrm{K}^{+}, \mathrm{Li}^{+}, \mathrm{Fe}^{+2}, \mathrm{Ra}^{+2}, \mathrm{Fe}^{+3}, \mathrm{Co}^{+2}, \mathrm{Co}^{+3}, \mathrm{Mn}^{+2}, \mathrm{Br}^{-}, \mathrm{NO}_{3}^{-}$, and $\mathrm{HCO}_{3}^{-}$but were considered out of the scope of the current model. In this study, an averaged composition of a hydraulic fracturing produced water obtained from the Marcellus Shale in New York reported in the literature was chosen to represent the water chemistry of the hypersaline water system (details are provided in Table 1) [22]. The ion concentrations were averaged from field-derived produced water samples generated from the Marcellus shale [22] unless otherwise noted.Bicarbonate $\left(\mathrm{HCO}_{3}{ }^{-}\right)$was found in a single sample at very low concentration $(48 \mathrm{mg} / \mathrm{L})$ so it was not included in the model. Hence, only chloride and sulfate were considered. To preserve electro-neutrality, $\mathrm{Cl}^{-}$was adjusted to $90,869 \mathrm{mg} / \mathrm{L}$, which is less than $5 \%$ different from the reported average $\mathrm{Cl}^{-}$ value for these samples, $86,457 \mathrm{mg} / \mathrm{L}$ [22].

Alkaline earth metals, such as $\mathrm{Ca}^{2+}, \mathrm{Ba}^{2+}, \mathrm{Mg}^{2+}$ and $\mathrm{Sr}^{2+}$ can readily form sulfate and carbonate scales even at low temperatures. Therefore, the objective of the softening steps is to reduce the concentration of potential scale-forming salts before thermal desalination treatment. Two scenarios were considered for the softening step: A) eonventional chemical precipitation using soda ash and, B) precipitation by mineralization with $\mathrm{CO}_{2}$. Both scenarios stepwise remove most divalent cations.

All chemical pretreatment reactors were assumed to reach chemical equilibrium by using a Gibbs-type reactor. For Scenario A, depicted in Fig. 1, a stoichiometric amount of sodium sulfate (on a $\mathrm{Ba}^{2+}$ molar basis) is mixed into the brine in the agitated sulfation reactor to preferentially remove $\mathrm{Ba}^{2+}$ ions in the form of barium sulfate (barite). The advantage of using sodium sulfate 
as the precipitating reagent as opposed to sulfuric acid is that it does not lower brine $\mathrm{pH}$ which in turn would increase the solubility of carbonate salts [22]. After solid/liquid separation in tank 1, the hypersaline water is mixed with a $50 \mathrm{wt}$. \% sodium hydroxide solution in the $\mathrm{pH}$ tank to precipitate $\mathrm{Mg}^{2+}$ as highly insoluble alkaline scale, $\mathrm{Mg}(\mathrm{OH})_{2}$. Magnesium hydroxide is separated from the brine in the solid/liquid separation step in tank 2. Then, the concentration of the remaining alkaline earth metals, mainly $\mathrm{Ca}^{2+}$ and $\mathrm{Sr}^{2+}$ are reduced by adding a stoichiometric amount of sodium carbonate (soda ash). Calcium carbonate and strontium carbonate scales are formed in this step and separated in the solid/liquid separation step in tank 3. This chemical precipitation protocol has been previously reported in the literature [23, 24].

For scenario B (shown in Fig. 2), barium sulfate is precipitated as in scenario A. The pH tank step requires an excess addition of $\mathrm{NaOH}$ to adjust $\mathrm{pH}$ so as to allow the subsequent precipitation of carbonate salts. The concentration of $\mathrm{Ca}^{2+}$ and $\mathrm{Sr}^{2+}$ ions is finally reduced by injecting an excess amount of $\mathrm{CO}_{2}$ (x 2) into the brine. Same as in Scenario A, calcium carbonate and strontium carbonate scales are precipitated and collected in tank 3.

The final processing area is identical for either scenario A or B, the goal is to remove the remaining dissolved salts. First, the pretreated brine is pressurized in a centrifugal high-pressure pump to $22.1 \mathrm{MPa}$, which is just above the supercritical pressure of pure water (22.06 MPa). Pressurized brine is then fed into a heat exchanger where it is pre-heated to $110{ }^{\circ} \mathrm{C}$ with the water vapor obtained on a subsequent FLASH separation. Subsequently, the pre-heated brine is heated to $362{ }^{\circ} \mathrm{C}$ with the vapor exiting the SCW-R step. The supercritical water reactor (SCWR) unit - simulated with a FLASH2 model - separates the stream into water vapor and saturated brine at $430{ }^{\circ} \mathrm{C}$. In order to maintain the SCW-R temperature, an internal electrode is assumed to continuously provide Joule-heating to the liquid phase. Finally, the saturated brine is flashed to a pressure of $0.1 \mathrm{MPa}$ (1 bar) where sodium salts, mainly $\mathrm{NaCl}$, can be recovered as a solid.

All the processes described above were simulated at steady-state using the Aspen Plus® v9 software. The thermodynamic properties were calculated using the electrolyte non-random twoliquid (ELECNRTL) method. This activity-based property method is suitable for a wide range of ion concentrations and operating conditions. Experimental results (not shown here) validate 
important properties utilized to estimate energy balances. The water chemistry employed in the simulation is provided in Appendix A.

\subsection{Economic Assessment}

In order to size the major pieces of equipment, the material balances obtained from the Aspen Plus ${ }^{\circledR}$ model were combined with reported or estimated residence times. Equipment costs were calculated and compared from different sources including the Aspen Process Economic Analyzer (APEA) tool imbedded in Aspen Plus ${ }^{\circledR}$ v9, Aspen Exchanger Design and Rating v9, cost charts, and vendor quotes. The material and energy balances calculated using Aspen Plus® were the basis for estimating the cost of raw materials and utilities, respectively. Table 2 details the base values and ranges employed in the operating cost analysis. The ranges were inspired on current chemical bulk prices (Alibaba website) at typical commercial purities. The credit taken for the products was considered to range from zero to commercial values, thus a conservative price was selected for the base case. It is worthwhile noting that $\mathrm{CO}_{2}$ was computed as a credit and that the natural gas generator had an efficiency of $58 \%$. The cost model was assembled in an excel spreadsheet. The year-basis for the capital cost estimation is 2015. All results and analysis are provided in U.S. dollars.

\section{Results and Discussion}

Desalination by conventional water recovery methods typically produces a concentrated contaminant stream which can have a considerable environmental impact and disposal cost. ZLD processes may allow for a more environmentally responsible disposal; however, processing cost may be a limiting factor. Figures 3 and 4 provide the flowsheet of the Aspen Plus ${ }^{\circledR}$ simulation for scenario A and B, respectively. The latter option, has the potential to reduce the in situ carbon footprint at the desalination facility.

\subsection{Material balance results for Scenario A}


The FEED stream is defined as an input to the simulation using the design composition previously discussed (Table 1). The concentration of $\mathrm{H}_{3} \mathrm{O}^{+}$in the FEED stream can be used to estimate an initial $\mathrm{pH}$ of 6.6. With the addition of sodium sulfate (NA2SO4 stream), a reduction of $99.5 \%$ in $\mathrm{Ba}^{2+}$ ions occur in the SULFTANK step and solid $\mathrm{BaSO}_{4}$ is preferentially precipitated as barite (solubility product, $K_{s p}=1.08 \times 10^{-10}$ at $25^{\circ} \mathrm{C}$ ) at a flowrate of $1527.2 \mathrm{~kg} / \mathrm{h}$ (Eqns. 1 and 2). The model also predicted the formation of a much smaller amount of $\mathrm{SrSO}_{4}$ at a flowrate of $2.8 \mathrm{~kg} / \mathrm{h}$ (Eq. 3).

$$
\begin{aligned}
& \mathrm{Na}_{2} \mathrm{SO}_{4} \leftrightarrow 2 \mathrm{Na}^{+}+\mathrm{SO}_{4}^{-2} \\
& \mathrm{Ba}^{+2}+\mathrm{SO}_{4}^{-2} \leftrightarrow \mathrm{BaSO}_{4} \\
& \mathrm{Sr}^{+2}+\mathrm{SO}_{4}^{-2} \leftrightarrow \mathrm{SrSO}_{4}
\end{aligned}
$$

For the purpose of this study, the SEP units were assumed to separate all solid products. The $\mathrm{NaOH}$ mixed in the PHTANK reacts with $\mathrm{Mg}^{2+}$ ions resulting in $99.0 \%$ removal as $\mathrm{Mg}(\mathrm{OH})_{2}$ with the following mechanism (Eqns. 4-6):

$$
\begin{aligned}
& \mathrm{NaOH} \leftrightarrow \mathrm{OH}^{-}+\mathrm{Na}^{+} \\
& \mathrm{OH}^{-}+\mathrm{Mg}^{+2} \leftrightarrow \mathrm{MgOH}^{+} \\
& \mathrm{OH}^{-}+\mathrm{MgOH}^{+} \leftrightarrow \mathrm{Mg}(\mathrm{OH})_{2}
\end{aligned}
$$

The sodium carbonate mixed in the last chemical pre-treatment step removes approximately $99.7 \%$ and $99.8 \%$ for $\mathrm{Ca}^{2+}$ and $\mathrm{Sr}^{2+}$ ions, respectively (Eqns. 7-9).

$$
\begin{aligned}
& \mathrm{Na}_{2} \mathrm{CO}_{3} \leftrightarrow 2 \mathrm{Na}^{+}+\mathrm{CO}_{3}^{-2} \\
& \mathrm{CO}_{3}^{-2}+\mathrm{Ca}^{+2} \leftrightarrow \mathrm{CaCO}_{3} \\
& \mathrm{CO}_{3}^{-2}+\mathrm{Sr}^{+2} \leftrightarrow \mathrm{SrCO}_{3}
\end{aligned}
$$

The chemically pre-treated brine enters the HPP unit where the pressure is increased from 0.1 to 22.1 MPa. Then, the brine is pre-heated in the first heat exchanger (COOL-1) to $110^{\circ} \mathrm{C}$. In order, to prevent a temperature cross over in the second heat exchanger (HX) the brine is heated to 362 ${ }^{\circ} \mathrm{C}$. Under these conditions no water vapor is expected to form inside the HX unit. The main water/salt separation occurs during the SCW-R step. The simulation is able to accurately predict 
the vapor mass fraction split at the SCW-R unit $(\mathrm{x}=0.74)$ within a percent difference from that of the pure $\mathrm{NaCl}-\mathrm{H}_{2} \mathrm{O}$ binary system $\left(\mathrm{x}=0.73\right.$ at $22.0 \mathrm{MPa}$ and $430{ }^{\circ} \mathrm{C}$ ) [25]. However, the simulation fails to predict any salts splitting into the HOT-IN vapor stream. In other words, pure water appears to evaporate from the brine solution in the SCW-R step. According to the literature, under those conditions the $\mathrm{NaCl}$ concentration in the vapor stream is in the order of $0.017 \mathrm{wt} \% \mathrm{NaCl}(170 \mathrm{mg} / \mathrm{l})$ [25]. In practice, this $\mathrm{NaCl}$ concentration may be small enough to have a negligible impact in the heat exchanger $(\mathrm{HX})$ calculation.

The concentrated liquid-phase effluent produced in the SCW-R step, SATBRINE, has a sodium chloride concentration of 51.8 wt. \%. Given that no $\mathrm{NaCl}$ is removed with the vapor fluid during the SCW-R step, this concentration is slightly higher than the 49.4 wt. \% reported in the literature for the $\mathrm{NaCl}$-water binary system [25]. A stream of 16,498 $\mathrm{kg}$ per hour of crystalline $\mathrm{NaCl}$ (solid) is finally obtained by flashing the SATBRINE stream to 1 bar. The model predicts smaller amounts of other salts present in this stream (e.g., strontium sulfate, calcium hydroxide, magnesium hydroxide). Water recovery is defined here as the ratio of water input to water output in treated water stream (TREATEDW). Overall, the conceptual process is able to recover $97 \%$ of the water entering the system as treated water.

\subsection{Material balance results for Scenario B}

Same as in Scenario A, $\mathrm{Ba}^{2+}$ ions are reduced $99.5 \%$. The excess $\mathrm{NaOH}$ added in the PHTANK step preferably reacts with $\mathrm{Mg}^{2+}$ ions resulting in a theoretical $100 \%$ removal (Eqns 4-6). In practice, this $\operatorname{Mg}(\mathrm{OH})_{2}$ product should be removed first, perhaps at a point where a stoichiometric amount of alkali has been used to avoid its contamination with any other partially insoluble alkali species like $\mathrm{Ca}(\mathrm{OH})_{2}$. The SOFT-IN stream has a $\mathrm{pH}$ of 11.6 before entering the SOFTTANK. Under this alkaline condition, dissolved $\mathrm{CO}_{2}$ forms the necessary $-\mathrm{CO}_{3}{ }^{2-}$ species (Eqns. 10-11) to precipitate the alkaline earth metal ions, thus removing $97.0 \%$ of $\mathrm{Ca}^{2+}$ and 98.3 $\%$ of $\mathrm{Sr}^{2+}$ ions from the SOFT- $\mathrm{H}_{2} \mathrm{O}$ stream (Eqns. 8-9)

$$
\begin{aligned}
& 2 \mathrm{H}_{2} \mathrm{O}+\mathrm{CO}_{2} \leftrightarrow \mathrm{HCO}_{3}^{-}+\mathrm{H}_{3} \mathrm{O}^{+} \\
& \mathrm{H}_{2} \mathrm{O}+\mathrm{HCO}_{3}^{-} \leftrightarrow \mathrm{H}_{3} \mathrm{O}^{+}+\mathrm{CO}_{3}^{-2}
\end{aligned}
$$


More details on the mechanisms of these reactions are provided elsewhere [26, 27]. At this point, the SOFT $-\mathrm{H}_{2} \mathrm{O}$ stream has an estimated $\mathrm{pH}$ of 6.2. The vapor fraction produced at the SCW-R unit is 0.75 . This fraction is slightly higher than the one in Scenario A due to the fact that a small amount of supercritical $\mathrm{CO}_{2}$ is present in the HOT-IN stream. The NA-SALTS stream composition predicted by the simulation is 99.2 wt. $\% \mathrm{NaCl}, 0.2$ wt. $\% \mathrm{Na}_{2} \mathrm{CO}_{3}$, and the remainder are other trace-minerals such as calcium carbonate, calcium hydroxide, barium carbonate, and strontium carbonate. The overall water recovery was estimated to be $97.8 \%$.

\subsection{Energy requirements}

Table 3 shows a comparison between the energy requirements for scenario A and B. The energy required in scenario A was projected to be lower than in scenario $\mathrm{B}$, due to a larger volumetric flowrate resulting from $50 \mathrm{wt}$ \% alkali solution addition. For both cases, the high pressure pump (HPP) was assumed to have an efficiency of 0.71. For the proposed Joule-heating desalination process, heat recovery at the heat exchanger (HX) is key for the economic feasibility of the process. The Aspen Plus ${ }^{\circledR}$ simulations resulted in a HX with LMTD of about $63{ }^{\circ} \mathrm{C}$ and a required exchanger area of $\sim 300 \mathrm{~m}^{2}$ (using a heat transfer coefficient of $3000 \mathrm{~W} / \mathrm{m}^{2} \cdot{ }^{\circ} \mathrm{C}$ ). The maximum temperature the brine can be preheated under the conditions of the simulation by heat integration alone (i.e., without the use of an external utility) under these conditions was $362^{\circ} \mathrm{C}$ which is $68{ }^{\circ} \mathrm{C}$ below the operation temperature of the SCW-R unit. The remainder of the energy needed to reach operating conditions was assumed to be provided by Joule heating within SCW$\mathrm{R}$ (this electrical power was assumed to be generated with natural gas). Odu and co-workers preheated their simulated seawater to $410{ }^{\circ} \mathrm{C}, 50{ }^{\circ} \mathrm{C}$ lower than the temperature in the supercritical water separation unit $\left(460^{\circ} \mathrm{C}\right)$, the heat recovery is higher because a higher supercritical water mass fraction can be obtained, 0.93, due to the lower salinity. In this study, the supercritical water fraction is only $0.74-0.75$.

Our experimental observations of the laboratory-scale SCW reactor $(\mathrm{V}=0.36 \mathrm{~L})$ revealed that it may be difficult to maintain the same temperature lengthways of the reactor (data not shown). AC current continuously applied to the electrode located at bottom of the insulated reactor may 
produce a zone of highest temperature, similar to the profile obtained near the reboiler in a distillation column. The opposite behavior may also be observed, when crystallization occurs and the liquid temperature drops while the vapor is at higher temperature. Therefore, for the purpose of the modeling, the SCW-R unit was assumed to operate isothermally at $430{ }^{\circ} \mathrm{C}$. The advantage of using internal Joule-heating as opposed to external heating is the instantaneous heat transfer, as opposed to heat transfer through thick reactor walls. and thinner reactor walls due to internat heating. Assuming no electrical losses and a well-insulated reactor, the electrical energy required to heat the SCW-R unit was predicted to be $180 \mathrm{kWh} / \mathrm{m}^{3}$ feed $\left(647 \mathrm{MJ} / \mathrm{m}^{3}\right)$ and $202 \mathrm{kWh} / \mathrm{m}^{3}$ feed $\left(726 \mathrm{MJ} / \mathrm{m}^{3}\right)$ for scenario $\mathrm{A}$ and $\mathrm{B}$, respectively. These results falls in trend with those reported by Odu and coworkers [17] as concentration increased $\left(410 \mathrm{MJ} / \mathrm{m}^{3}\right.$ for pure water, 450 $\mathrm{MJ} / \mathrm{m}^{3}$ for 3.5 wt. $\% \mathrm{NaCl}$ ).

Note that our approach is similar to the one of Odu et al. in the sense that the brine is first concentrated to about $50 \mathrm{wt}$. \% and the solution is flashed afterwards to obtain the solid salts [17]. Other ZLD desalination designs have explored the separation of the solid salts at supercritical brine conditions during the SCW $R$ step [28, 29]. This may allow for more heat recovery in the HX step. However, one challenge of such configuration is the higher temperature and pressure required to reach supercritical conditions. Knight and Bodnar provided PVTX properties correlations for the $\mathrm{NaCl}-\mathrm{H}_{2} \mathrm{O}$ system [28]. According to these authors, the critical temperature and pressure can be obtained with the following correlations:

$T=374.1+8.800 \emptyset+0.1771 \emptyset^{2}-0.02113 \emptyset^{3}+7.334 \cdot 10^{-4} \emptyset^{4}$

$P=2094-20.56 T+0.06896 T^{2}-8.903 \times 10^{-5} T^{3}+4.214 \times 10^{-8} T^{4}$

Where $T$ is the critical temperature in degrees Celsius, $\phi$ is the $\mathrm{NaCl}$ concentration in wt. $\%$, and $P$ is the critical pressure in bars. For a solution of $15.5 \mathrm{wt} . \% \mathrm{NaCl}$, the critical temperature and critical pressure are estimated to be $512 \pm 4{ }^{\circ} \mathrm{C}$ and $604 \pm 21$ bars, respectively. Another 
correlation for the critical pressure and temperature is given by Driesner and Heinrich [29]. Using this approach, the critical temperature and critical pressure at the same concentration are computed as $523^{\circ} \mathrm{C}$ and 659 bars, respectively.

In addition to the high temperature and pressure required to achieve supercritical conditions, there is also the challenge for continuous removal of the solid crystals forming inside the SCW-R unit. A spiral separator has been proposed for the continuous separation of the supercritical water product and minerals [30]. However, in our particular design, another reason to operate below the critical point of the system is that the novel Joule-heating approach may function more efficiently when a liquid phase is present to conduct the alternating current (AC).

For both scenarios $\mathrm{A}$ and $\mathrm{B}$, when the temperature and pressure of the SATBRINE stream are dropped to $350^{\circ} \mathrm{C}$ and $0.1 \mathrm{MPa}(1 \mathrm{bar})$ respectively, the model predicts complete salts separation in the FLASH unit. Finally, the resulting treated water streams are cooled from about $99{ }^{\circ} \mathrm{C}$ to 25 ${ }^{\circ} \mathrm{C}$. Table 3 also details the amount of heat that can be potentially recovered from the treated water streams.

A universal goal in desalination is to minimize process energy requirement. Thiel and coworkers recently compared the energy consumption for various water recovery desalination systems treating high salinity feedstock [16]. Here, the final concentrated brine product had a constant salinity of $26 \%$ (which is the $\mathrm{NaCl}$-water saturation limit at normal conditions). Using the second law of efficiency as a metric - the ratio of the least amount of work required for separation of the concentrated brine and the water product to the system exergy input - the authors concluded that evaporative systems operated more efficiently than RO membranes at higher feed salinities due to their lower energy sensitivity to salinity.

\subsection{Economic analysis}

The system capacity selected for the economic analysis was $113.6 \mathrm{~m}^{3}$ of hypersaline feed per hour (500 gallons per minute). For this nominal capacity, we envisioned a system that can be mobile or skid-mounted so that it can be used where the brine is being produced (e.g., 
wastewater treatment plants, gas well sites, $\mathrm{CO}_{2}$ injection operations, $\mathrm{RO}$ membrane desalination).

The estimated equipment cost for the conceptual process is detailed in Tble 4. As expected from the operating conditions, the major cost items were found to be the HX and the SCW-R units. A large contributor to the cost of these units is the selection of construction material which have to withstand corrosion at high temperatures. It may be possible to employ less expensive construction materials, such as carbon steel by cladding a corrosion resistant coating. However, for the purpose of this analysis a more conservative estimate was employed. Both scenarios have a similar capital expense with preliminary estimate for total module cost of about \$8 M USD.

It is important to note the uncertainty in the current capital cost estimation. The current estimate should be considered to have an accuracy of $+40 /-25 \%$ [31]. For example, the cost of the HX is representative of different designs provided by Aspen Exchanger Design and Rating v9 as we currently lack resolution on the specific requirements of the heat exchanger. For costing purposes, a DMU (high-pressure enclosure, multiple tube hairpin, U-tube bundle) type heat exchanger was selected. In addition, the residence time in the SCW-R is one of the largest uncertainties in this analysis, but is expected to be than one minute based upon experimental trials completed to date. As a first approximation, the multi-phase reactor cost (SOFTTANK in Scenario B) was estimated using the cost of an agitated tank x 1.5.

Contingency costs (also in Table 4) may include for example, sludge pumps, valves, holding tanks, UV unit, solids filters, recovery of naturally occurring radioactive materials (NORM), generators, etc. This cost was assessed as $10 \%$ of the major equipment cost. In this study, the Total Module Cost was employed instead of Total Grassroots Costs as the former represents small-to-moderate expansion or alterations within the site. This assumption follows the rationale that the desalination plant will operate at a current $\mathrm{CO}_{2}$ sequestration facility, seawater desalination plant, or an oil/gas operation.

Figure 5 shows the comparison of direct manufacturing costs for scenario A and B using the base values in Table 2. As expected, the cost of raw materials sodium sulfate, sodium hydroxide and sodium carbonate (in A) as well as the power to the reactor (>90\% of utilities) were the major OPEX expenditures. The major difference between the two scenarios is the cost of raw materials. While capturing $\mathrm{CO}_{2}$ in Scenario B may be desirable from an environmental standpoint, the cost 
of increasing the $\mathrm{pH}$ (with sodium hydroxide) may not economically compensate the benefit of reducing the carbon footprint. Scenario B could represent a more economically sustainable solution when the cost of capturing $\mathrm{CO}_{2}$ is higher than $\$ 40$ per ton or when a lower cost alkali material is used to increase the $\mathrm{pH}$ of the brine, such as fly ashes. Soong and coworkers found that $\mathrm{CaO}$-rich fly ashes (Class $\mathrm{C}$ and FGD types) were effective at increasing the $\mathrm{pH}$ level of the brine to permanently sequester $\mathrm{CO}_{2}$ as carbonate minerals [32]. The value contribution from the minerals produced in Scenario A and B was similar, 43\% from calcium and strontium carbonate, $34 \%$ from sodium chloride, $21 \%$ from barium sulfate, and $2 \%$ from magnesium hydroxide.

Table 5 shows the breakeven cost results for a barrel of treated water under scenarios A and B. In order to annualize the capital investment we employed the compound interest formula (Eq. 14).

$A=P \cdot \frac{i(1+i)^{n}}{(1+i)^{n}-1}$

Where $A$ is the annualized payment in U.S. dollars per year; $P$ is the principal value in U.S. dollars; $i$ is the interest rate $(5 \%)$ and $n$ is the number of years (9.5 years).

The base economic model incorporates credits for the minerals produced and the model is highly sensitive to this parameter. The model predicts a desalination cost of $\$ 4.29$ per $\mathrm{m}^{3}$ feed (\$0.68/bbl feed) for Scenario A and $\$ 7.82$ per $\mathrm{m}^{3}$ feed $(\$ 1.24 / \mathrm{bbl}$ feed) for scenario B. When no credit is allocated to these mineral products, the cost to treat the hypersaline brine may be greater than $\$ 3 / \mathrm{bbl}$. No taxation structure is considered on the sale of mineral salts the analysis.

The model is also sensitive to energy costs. For the lower boundary of natural gas cost, $\$ 0.0068$ per $\mathrm{kWh}$ (2.0 MMBTU), the model predicts more competitive desalination cost of $\$ 2.63$ per $\mathrm{m}^{3}$ feed $(\$ 0.42 / \mathrm{bbl})$ for Scenario A and $\$ 5.96$ per $\mathrm{m}^{3}$ feed $(\$ 0.95 / \mathrm{bbl})$ for scenario B. Other parameters, such as the cost of cooling water [31] were found to have little impact in the overall cost.

A comparison of reported cost values found in the literature with the ones provided in this study is summarized in Table 6. Sullivan and coworkers modeled the treatment of brackish water $(10,000-35,000 \mathrm{mg} / \mathrm{L})$ extracted from a saline aquifer during geological $\mathrm{CO}_{2}$ sequestration using reverse osmosis (RO) [4]. Their model showed the cost increases with increasing TDS 
concentration from approximately $\$ 0.30 / \mathrm{m}^{3}$ to about $\$ 1.65 / \mathrm{m}^{3}$ of output treated water for either $50 \%$ or $90 \%$ recovery. For higher TDS water feedstock $(50,000 \mathrm{mg} / \mathrm{L})$, as found in the shale and gas operations, Ziemkiewicz and team found the cost of RO to be $\$ 6.94$ per 1000 gal $\left(\$ 1.83 / \mathrm{m}^{3}\right)$

Caldera et al. estimated a global projected cost for the reverse osmosis of seawater using renewable energy [15]. The projected global cost for the year 2030 was calculated to be between $0.59 € / \mathrm{m}^{3}-2.81 € / \mathrm{m}^{3}$ of water produced. This cost would translate to approximately $\$ 0.62 / \mathrm{m}^{3}-$ $\$ 2.97 / \mathrm{m}^{3}$ of output treated water. Neither RO nor other membrane treatment technologies produce a zero liquid discharge. Therefore, a direct cost comparison is not possible with the technology evaluated in this study. In fact, these filtration technologies may produce a stream that is even more difficult to treat and known to have an adverse effect on the environment [2, 19].

The cost for an integrated ZLD system that combine membranes and thermal treatments has been reviewed for seawater desalination [19]. The cost of desalinated water for two combinations UF (ultrafiltration)-NF (nanofiltration)-MSF (multi stage flash)-crystallization, and UF-NF-ROMSF-Crystallization was computed to be $\$ 0.71 / \mathrm{m}^{3}$ and $\$ 0.43 / \mathrm{m}^{3}$, respectively. However, the utilization of membranes for high salinity feedstock is not yet feasible [33].

The cost of lined evaporative ponds (LEP), which can also be considered a ZLD method, has been reported to be $\$ 27.56$ per 1000 gallons of treated water $\left(\$ 7.28 / \mathrm{m}^{3}\right)$ [34]. The current economic feasibility evaluation for our desalination technology $\left(\$ 4.58 / \mathrm{m}^{3}\right.$ to $\$ 7.80 / \mathrm{m}^{3}$ treated water) compares well with that of LEP. Then, the proposed technology may be employed as a more comprehensive waste reduction strategy or be beneficial in regions where treated water has a premium market value. Other treatments that produce ZLD streams, like lined evaporative pends may cost $\$ 1.16 / b b 1[34]$.

\section{Conclusions and Perspectives}

This study provides preliminary cost data for the desalination of hypersaline feedstock using a Joule-heated supercritical water and zero liquid discharge approach. The cost of processing the

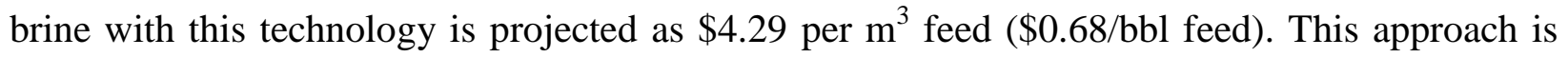


expected to produce no contaminant liquid streams. Future work will be focused in the minimization of energy requirements and the possibility of using membranes as the pre treatment technology. Current experimental work is exploring the possibility to reduce the number of stages required in the process. Future work will focus on the determination of the environmental footprint of this novel approach in comparison with other technologies.

\section{Available materials}

The Aspen models and economic spreadsheets are available upon request to the corresponding authors.

\section{Acknowledgments}

This work was supported by the Department of Energy [DOE Cooperative Agreement No. DEFE0026315].

\section{Appendix A}

Table A.1 Aspen Plus® model chemistry.

\begin{tabular}{|l|l|c|}
\hline Reaction Type & Chemical Equation & \\
\hline Equilibrium & $\mathrm{MgOH}^{+} \leftrightarrow \mathrm{OH}^{-}+\mathrm{Mg}^{+2}$ & (A. 1) \\
\hline Equilibrium & $\mathrm{CaOH}^{+} \leftrightarrow \mathrm{OH}^{-}+\mathrm{Ca}^{+2}$ & (A. 2) \\
\hline Equilibrium & $\mathrm{H}_{2} \mathrm{O}+\mathrm{HSO}_{4}^{-2} \leftrightarrow \mathrm{H}_{3} \mathrm{O}^{+}+\mathrm{SO}_{4}^{+2}$ & (A. 3) \\
\hline Equilibrium & $\mathrm{H}_{2} \mathrm{O}+\mathrm{HCl}^{+2} \mathrm{H}_{3} \mathrm{O}^{+}+\mathrm{Cl}^{-}$ & (A. 4) \\
\hline Equilibrium & $\mathrm{H}_{2} \mathrm{O}+\mathrm{H}_{2} \mathrm{SO}_{4} \leftrightarrow \mathrm{H}_{3} \mathrm{O}^{+}+\mathrm{HSO}_{4}^{-}$ & (A. 5) \\
\hline Equilibrium & $\mathrm{H}_{2} \mathrm{O}+\mathrm{HCO}_{3}^{-} \leftrightarrow \mathrm{H}_{3} \mathrm{O}^{+}+\mathrm{CO}_{3}^{-2}$ & (A. 6) \\
\hline Equilibrium & $2 \mathrm{H}_{2} \mathrm{O} \leftrightarrow \mathrm{H}_{3} \mathrm{O}^{+}+\mathrm{OH}^{-}$ & (A. 7) \\
\hline
\end{tabular}




\begin{tabular}{|c|c|c|}
\hline Equilibrium & $2 \mathrm{H}_{2} \mathrm{O}+\mathrm{CO}_{2} \leftrightarrow \mathrm{HCO}_{3}^{-}+\mathrm{H}_{3} \mathrm{O}^{+}$ & (A. 8) \\
\hline Equilibrium & $\mathrm{Sr}(\mathrm{OH})^{+} \leftrightarrow \mathrm{OH}^{-}+\mathrm{Sr}^{+2}$ & (A.9) \\
\hline Equilibrium & $\mathrm{Ba}(\mathrm{OH})^{+} \leftrightarrow \mathrm{OH}^{-}+\mathrm{Ba}^{+2}$ & (A. 10) \\
\hline Salt & $\mathrm{MgCO}_{3} \cdot 3 \mathrm{H}_{2} \mathrm{O} \leftrightarrow \mathrm{CO}_{3}^{-2}+\mathrm{Mg}^{+2}+3 \mathrm{H}_{2} \mathrm{O}$ & (A. 11) \\
\hline Salt & $\mathrm{MgCO}_{3} \leftrightarrow \mathrm{CO}_{3}^{-2}+\mathrm{Mg}^{+2}$ & (A. 12) \\
\hline Salt & $\mathrm{CaCO}_{3} \leftrightarrow \mathrm{CO}_{3}^{-2}+\mathrm{Ca}^{+2}$ & (A. 13) \\
\hline Salt & $\mathrm{Mg}(\mathrm{OH})_{2} \leftrightarrow \mathrm{OH}^{-}+\mathrm{MgOH}^{+}$ & (A. 14) \\
\hline Salt & $\mathrm{Ca}(\mathrm{OH})_{2} \leftrightarrow \mathrm{OH}^{-}+\mathrm{CaOH}^{+}$ & (A. 15) \\
\hline Salt & $\mathrm{Na}_{2} \mathrm{CO}_{3} \cdot 7 \mathrm{H}_{2} \mathrm{O} \leftrightarrow 2 \mathrm{Na}^{+}+\mathrm{CO}_{3}^{-2}+7 \mathrm{H}_{2} \mathrm{O}$ & (A. 16) \\
\hline Salt & $\mathrm{Na}_{2} \mathrm{CO}_{3} \leftrightarrow 2 \mathrm{Na}^{+}+\mathrm{CO}_{3}^{-2}$ & (A. 17) \\
\hline Salt & $\mathrm{NaOH} \leftrightarrow \mathrm{OH}^{-}+\mathrm{Na}^{+}$ & (A. 18) \\
\hline Salt & $\mathrm{SrCl}_{2} \cdot 2 \mathrm{H}_{2} \mathrm{O} \leftrightarrow \mathrm{Sr}^{+2}+2 \mathrm{H}_{2} \mathrm{O}+2 \mathrm{Cl}^{-}$ & (A. 19) \\
\hline Salt & $\mathrm{SrCl}_{2} \cdot 6 \mathrm{H}_{2} \mathrm{O} \leftrightarrow \mathrm{Sr}^{+2}+6 \mathrm{H}_{2} \mathrm{O}+2 \mathrm{Cl}^{-}$ & (A. 20) \\
\hline Salt & $\mathrm{SrCl}_{2} \leftrightarrow \mathrm{Sr}^{+2}+2 \mathrm{Cl}^{-}$ & (A. 21) \\
\hline Salt & $\mathrm{BaCl}_{2} \leftrightarrow \mathrm{Ba}^{+2}+2 \mathrm{Cl}^{-}$ & (A. 22) \\
\hline Salt & $\mathrm{Na}_{2} \mathrm{SO}_{4} \cdot 10 \mathrm{H}_{2} \mathrm{O} \leftrightarrow 2 \mathrm{Na}^{+}+\mathrm{SO}_{4}^{-2}+10 \mathrm{H}_{2} \mathrm{O}$ & (A. 23) \\
\hline Salt & $\mathrm{Na}_{2} \mathrm{SO}_{4} \leftrightarrow 2 \mathrm{Na}^{+}+\mathrm{SO}_{4}^{-2}$ & (A. 24) \\
\hline Salt & $\mathrm{NaCl} \leftrightarrow \mathrm{Na}^{+}+\mathrm{Cl}^{-}$ & (A. 25) \\
\hline Salt & $\mathrm{SrSO}_{4} \leftrightarrow \mathrm{Sr}^{+2}+\mathrm{SO}_{4}^{-2}$ & (A. 26) \\
\hline Salt & $\mathrm{BaSO}_{4} \leftrightarrow \mathrm{Ba}^{+2}+\mathrm{SO}_{4}^{-2}$ & (A. 27) \\
\hline Salt & $\mathrm{NaOH} \cdot \mathrm{H}_{2} \mathrm{O} \leftrightarrow \mathrm{OH}^{-}+\mathrm{Na}^{+}+\mathrm{H}_{2} \mathrm{O}$ & (A. 28) \\
\hline Salt & $\mathrm{Na}_{2} \mathrm{CO}_{3} \cdot \mathrm{H}_{2} \mathrm{O} \leftrightarrow 2 \mathrm{Na}^{+}+\mathrm{CO}_{3}^{-2}+\mathrm{H}_{2} \mathrm{O}$ & (A. 29) \\
\hline Salt & $\mathrm{BaCO}_{3} \leftrightarrow \mathrm{Ba}^{+2}+\mathrm{CO}_{3}^{-2}$ & (A. 30) \\
\hline
\end{tabular}




\begin{tabular}{|c|c|c|}
\hline Salt & $\mathrm{SrCO}_{3} \leftrightarrow \mathrm{Sr}^{+2}+\mathrm{CO}_{3}^{-2}$ & (A. 31) \\
\hline Salt & $\mathrm{CaSO}_{4} \leftrightarrow \mathrm{Ca}^{+2}+\mathrm{SO}_{4}^{-2}$ & (A. 32) \\
\hline Salt & $\mathrm{BaSO}_{4} \leftrightarrow \mathrm{Ba}^{+2}+\mathrm{SO}_{4}^{-2}$ & (A. 33) \\
\hline Salt & $\mathrm{Ba}(\mathrm{OH})_{2} \leftrightarrow \mathrm{Ba}(\mathrm{OH})^{+}+\mathrm{OH}^{-}$ & (A. 34) \\
\hline Salt & $\mathrm{Sr}(\mathrm{OH})_{2} \leftrightarrow \mathrm{Sr}(\mathrm{OH})^{+}+\mathrm{OH}^{-}$ & (A. 35) \\
\hline Dissociation & $\mathrm{Mg}(\mathrm{OH})_{2} \rightarrow \mathrm{OH}^{-}+\mathrm{MgOH}^{+}$ & (A. 36) \\
\hline Dissociation & $\mathrm{Na}_{2} \mathrm{CO}_{3} \rightarrow 2 \mathrm{Na}^{+}+\mathrm{CO}_{3}^{-2}$ & (A. 37) \\
\hline Dissociation & $\mathrm{MgCO}_{3} \rightarrow \mathrm{CO}_{3}^{-2}+\mathrm{Mg}^{+2}$ & (A. 38) \\
\hline Dissociation & $\mathrm{CaCO}_{3} \rightarrow \mathrm{CO}_{3}^{-2}+\mathrm{Ca}^{+2}$ & (A. 39) \\
\hline Dissociation & $\mathrm{NaOH} \rightarrow \mathrm{OH}^{-}+\mathrm{Na}^{+}$ & (A. 40) \\
\hline Dissociation & $\mathrm{SrSO}_{4} \rightarrow \mathrm{Sr}^{+2}+\mathrm{SO}_{4}^{-2}$ & (A. 41) \\
\hline Dissociation & $\mathrm{BaSO}_{4} \rightarrow \mathrm{Ba}^{+2}+\mathrm{SO}_{4}^{-2}$ & (A. 42) \\
\hline
\end{tabular}

\section{References}

1. GWI, IDA Desalination Yearbook 2016-2017. 2016.

2. Giwa, A., et al., Engineering advance: Brine management methods: Recent innovations and current status. Desalination, 2017. 407: p. 1-23.

3. Chen, H. and K.E. Carter, Water usage for natural gas production through hydraulic fracturing in the United States from 2008 to 2014. Journal of Environmental Management, 2016: p. 152.

4. Sullivan, E.J., et al., A method and cost model for treatment of water extracted during geologic CO2 storage. International Journal of Greenhouse Gas Control, 2013. 12: p. 372-381.

5. Sullivan Graham, E.J., S. Chu, and R.J. Pawar, Probabilistic cost estimation methods for treatment of water extracted during CO2 storage and EOR. International Journal of Greenhouse Gas Control, 2015. 41: p. 316-327.

6. Kobos, P.H., et al., Combining power plant water needs and carbon dioxide storage using saline formations: Implications for carbon dioxide and water management policies. International Journal of Greenhouse Gas Control, 2011. 5: p. 899-910.

7. Christie, C., Disposal of Produced Water from Oil \& Gas Exploration: Environmental Impacts on Waterways in Western Pennsylvania. 2012, Duke University.

8. Aybar, H.S., Analysis of a mechanical vapor compression desalination system. Desalination, 2002. 142: p. 181-186. 
9. Aly, N.H. and A.K. El-Figi, Mechanical vapor compression desalination systems - A case study. Desalination, 2003. 158: p. 143-150.

10. El-ghonemy, A.M.K., Waste energy recovery in seawater reverse osmosis desalination plants. Part 1: Review. Renewable and Sustainable Energy Reviews, 2013. 18: p. 6-22.

11. Henthorne, L. and B. Boysen, State-of-the-art of reverse osmosis desalination pretreatment. Desalination, 2015. 356: p. 129-139.

12. Gude, V.G., Geothermal source potential for water desalination - Current status and future perspective. Renewable and Sustainable Energy Reviews, 2016: p. 1038.

13. Esfahani, I.J., et al., Efficient thermal desalination technologies with renewable energy systems: $A$ state-of-the-art review. Korean Journal of Chemical Engineering, 2016(2): p. 351.

14. Reif, J.H. and W. Alhalabi, Solar-thermal powered desalination: Its significant challenges and potential. Renewable and Sustainable Energy Reviews, 2015. 48: p. 152-165.

15. Caldera, U., D. Bogdanov, and C. Breyer, Local cost of seawater RO desalination based on solar PV and wind energy: A global estimate. Desalination, 2016. 385: p. 207-216.

16. Thiel, G.P., et al., Energy consumption in desalinating produced water from shale oil and gas extraction. Desalination, 2015: p. 94.

17. Odu, S.O., et al., Design of a Process for Supercritical Water Desalination with Zero Liquid Discharge. Industrial and Engineering Chemistry Research, 2015. 54(20): p. 5527-5535.

18. Davis, T.A., Water desalination process and apparatus. 2008.

19. Morillo, J., et al., Comparative study of brine management technologies for desalination plants. Desalination, 2014. 336: p. 32-49.

20. Lummen, $\mathrm{N}$. and $\mathrm{B}$. Kvamme, Kinetics of $\mathrm{NaCl}$ nucleation in supercritical water investigated by molecular dynamics simulations.

21. OilPaq, Fracking flowback and produced water treatment in the US. Filtration + Separation, 2015. 52(4): p. 16-17.

22. Thiel, G.P. and J.H. Lienhard V, Treating produced water from hydraulic fracturing: Composition effects on scale formation and desalination system selection. Desalination, 2014. 346: p. 54-69.

23. DiTommaso, F.A. and P.N. DiTommaso, Method of making pure salt from FRACwater/wastewater. 2012.

24. Blumenschein, C.D., H. M.W., and K. Banerjee, Method for Removing Calcium, Barium, Magnesium and Strontium From Frac Flowback. 2013, Veolia Water Soultions \& Technologies Support: USA.

25. Bischoff, J.L. and K.S. Pitzer, Liquid-vapor relations for the system NaCl-H2O: summary of the P-T$x$ surface from 300 degrees to 500 degrees Celsius. American Journal of Science, 1989(3): p. 217.

26. Zhao, Y., et al., Mechanism studies of a CO2 participant softening pretreatment process for seawater desalination. Desalination, 2016. 393: p. 166-173.

27. Kang, K.C., et al., Seawater desalination by gas hydrate process and removal characteristics of dissolved ions ( $\mathrm{Na}+, \mathrm{Kt}, \mathrm{Mg2t}, \mathrm{Ca2+}, \mathrm{B3+}, \mathrm{Cl}$-, SO42-). Desalination, 2014. 353: p. 84-90.

28. Bodnar, R., Synthetic fluid inclusions. IX. Critical PVTX properties of NaCl-H sub 2 O. Geochimica et Cosmochimica Acta, 1989(1): p. 3.

29. Driesner, T. and C.A. Heinrich, The system H2O-NaCl. Part I: Correlation formulae for phase relations in temperature-pressure-composition space from 0 to $1000^{\circ} \mathrm{C}, 0$ to $5000 \mathrm{bar}$, and 0 to 1 $X \mathrm{NaCl}$. Geochimica et Cosmochimica Acta, 2007. 71: p. 4880-4901.

30. Lean, M.H., J. Seo, and A.R. Völkel, DESALINATION USING SUPERCRITICAL WATER AND SPIRAL SEPARATION. 2012.

31. Turton, R., Analysis, synthesis, and design of chemical processes. [electronic resource]. 2012: Upper Saddle River, NJ : Prentice Hall, c2012. 
4th ed.

32. Soong, Y., et al., CO2 sequestration with brine solution and fly ashes. Energy Conversion and Management, 2006. 47: p. 1676-1685.

33. Xiong, B., A.L. Zydney, and M. Kumar, Fouling of microfiltration membranes by flowback and produced waters from the Marcellus shale gas play. Water Research, 2016. 99: p. 162-170.

34. Ziemkiewicz, P.F., et al., Zero Discharge Water Management for Horizontal Shale Gas Well Development 2012, West Virginia Water Research Institute, FilterSure, Inc., ShipShaper, LLP. 
List of tables

\section{Table 1.}

Concentration of dissolved solids for the hypersaline water design case.

\begin{tabular}{|l|r|r|}
\hline Constituent & Mass concentration $(\mathbf{m g} / \mathbf{L})$ & Molarity (mol/L) \\
\hline $\mathrm{Na}^{+}$ & $37,939.0$ & 1.650 \\
\hline $\mathrm{Ca}^{2+}$ & $12,575.0$ & 0.314 \\
\hline $\mathrm{Ba}^{2+}$ & $7,944.6$ & 0.058 \\
\hline $\mathrm{Sr}^{2+}$ & $4,153.8$ & 0.047 \\
\hline $\mathrm{Mg}^{2+}$ & $1,106.4$ & 0.046 \\
\hline $\mathrm{Cl}^{-\underline{*}}$ & $90,869.3$ & 2.563 \\
\hline $\mathrm{SO}_{4}{ }^{2-}$ & 779.0 & 0.008 \\
\hline Total Dissolved Solids (TDS) $^{2-}$ & $155,336.1$ & \\
\hline
\end{tabular}

${ }^{*} \mathrm{Cl}^{-}$was estimated so as to preserve the electrochemical neutrality of the system. 


\section{Table 2.}

Base values employed in the economic analysis.

\begin{tabular}{|c|c|c|c|}
\hline Variables & Units & Base Value & Range \\
\hline CAPEX Interest Rate & $\%$ & 5 & NA \\
\hline Raw Material Cost & $\$ /$ ton & & \\
\hline Sodium sulfate & & 120 & $115-130$ \\
\hline Sodium hydroxide & & 350 & $320-480$ \\
\hline Sodium carbonate & & 140 & $90-200$ \\
\hline Carbon dioxide ${ }^{*}$ & & 40 & $20-60$ \\
\hline Product Credit & $\$ /$ ton & & \\
\hline Sodium Chloride & & 30 & $0-60$ \\
\hline Barium sulfate & & 200 & $0-450$ \\
\hline Magnesium Hydroxide & & 100 & $0-250$ \\
\hline Carbonates (Ca and $\mathrm{Sr}$ ) & & 150 & $0-300$ \\
\hline \multicolumn{4}{|l|}{ Utilities } \\
\hline Natural gas ${ }^{\ddagger}$-(to provide the & $\$ / \mathrm{kWh}$ & 0.012 & $0.007-0.020$ \\
\hline electricity for the electrode) & & & \\
\hline Cooling water & $\$ / G J_{\text {th }}$ & 0.354 & NA \\
\hline
\end{tabular}

${ }^{*}$ Computed in the model as a credit.

${ }^{\dagger}$ For electricity, the generation unit efficiency was assumed to be $58 \%$. 


\section{Table 3.}

Energy requirement for major processing steps in the multi-stage desalination system.

\begin{tabular}{|l|l|r|r|}
\hline Unit & Units & Scenario A & \multicolumn{1}{|c|}{ Scenario B } \\
\hline High pressure pump (HPP) $^{\mathrm{a}}$ & $\mathrm{kWh} / \mathrm{m}^{3}$ feed & 8.5 & 9.0 \\
\hline Heat Exchanger (HX) & $\mathrm{kWh} / \mathrm{m}^{3}$ feed & 513.1 & 536.9 \\
\hline Supercritical Water Reactor (SCW-R) & $\mathrm{kWh} / \mathrm{m}^{3}$ feed & 179.7 & 201.8 \\
\hline Flash (FLASH) & $\mathrm{kWh} / \mathrm{m}^{3}$ feed & 20.9 & 21.4 \\
\hline Heat Exchanger (COOL-1) & $\mathrm{kWh} / \mathrm{m}^{3}$ feed & 84.1 & 74.7 \\
\hline Heat Exchanger (COOL-2) & $\mathrm{kWh} / \mathrm{m}^{3}$ feed & 159.8 & 197.1 \\
\hline
\end{tabular}

${ }^{\mathrm{a}} \mathrm{\eta}_{\mathrm{p}}=0.71$ 


\section{Table 4.}

Fixed capital investment details for the conceptual Joule-desalination systems.

\begin{tabular}{|c|c|c|c|c|}
\hline Equipment & $\begin{array}{l}\text { Material of } \\
\text { Construction }\end{array}$ & Estimation method & $\begin{array}{c}\text { Scenario A } \\
\text { (M\$) }\end{array}$ & $\begin{array}{c}\text { Scenario B } \\
\text { (M\$) }\end{array}$ \\
\hline Sulftank & SS360 & APEA & 0.2 & 0.2 \\
\hline $\mathrm{pHtank}$ & SS360 & APEA & 0.2 & 0.2 \\
\hline softtank & SS360 & APEA & 0.2 & $0.4^{\frac{8}{5}}$ \\
\hline HPP & SS360 & APEA & 0.9 & 0.9 \\
\hline $\mathrm{HX}^{\zeta}$ & Hastelloy C & AEDR & 1.3 & 1.3 \\
\hline $\mathrm{SCW}-\mathrm{R}^{*}$ & Ni Alloy & Turton & 1.6 & 1.7 \\
\hline Flash & Ni Alloy & Turton & 0.9 & 1.0 \\
\hline Cool-1 & Carbon Steel & APEA & 0.4 & 0.5 \\
\hline Cool-2 & Carbon Steel & APEA & 0.4 & 0.4 \\
\hline Contingency $^{\ddagger}$ & $\mathrm{NA}$ & $10 \%$ major equipment & 0.6 & 0.7 \\
\hline Total & & & 6.7 & 7.3 \\
\hline Total Module Cost ${ }^{\star}$ & & $1.18 \times \sum_{i=1}^{n} C_{\mathrm{BM}}$ & 7.8 & 8.6 \\
\hline
\end{tabular}

${ }^{5}$ Cost is representative of different designs provided by Aspen Exchanger Design and Rating $v 9$.

*The SCW-R residence time is one of the largest uncertainties in this analysis. We expect this to be less than one minute. Future work will look at computational fluid modeling inside the reactor.

*** Due to the limited scope of our experimental testing, the flash process has not yet been validated.

${ }^{\dagger}$ Contingency for other equipment may include sludge pumps, valves, holding tanks, UV unit, filters, NORM treatment, generators.

*Total Module Cost is employed instead of Total Grassroots Costs as the former represent smallto-moderate expansion or alterations within the site (e.g., $\mathrm{CO}_{2}$-storage, desalination plant, oil/gas eperation).

${ }^{\S}$ The multi-phase reactor cost was estimated using the cost of an agitated tank $x 1.5$. 
Table 5.

Cost per barrel of treated brine.

\begin{tabular}{|l|r|r|}
\hline & Scenario A & Scenario B \\
\hline Annualized Capital Investment (M\$/yr) & 1.05 \\
\hline Annual operating cost (M\$/yr) & 14.63 & 17.37 \\
\hline Mineral credits (\$/year)* & -12.06 & -11.92 \\
\hline Feed flow rate (gal brine/min) & 500 & 500 \\
\hline Capacity factor & 0.85 & 0.85 \\
\hline Treatment Cost (\$/bbl brine) & 0.68 & 1.24 \\
\hline
\end{tabular}

$-^{\dagger}\left(\frac{A}{P}\right)_{n}^{i}=\frac{i(1+i)^{n}}{(1+i)^{n}-1}, i=5 \%$ and $n=9.5$ years.

* No taxation structure is considered on the sale of minerals in the analysis. 


\section{Table 6.}

Cost comparison for different desalination processes.

\begin{tabular}{|c|c|c|c|}
\hline Process & $\begin{array}{l}\text { Cost }\left(\$ / \mathrm{m}^{3}\right. \\
\text { treated water })\end{array}$ & Remarks & Ref. \\
\hline Reverse Osmosis & $0.30-1.65$ & $\begin{array}{l}\text { Not ZLD, brackish water } \\
\text { desalination }\end{array}$ & [4] \\
\hline Reverse Osmosis & 1.83 & $\begin{array}{l}\text { Not ZLD, shale gas hydraulic } \\
\text { fracturing water desalination }\end{array}$ & [15] \\
\hline Reverse Osmosis & $0.59-2.81$ & $\begin{array}{l}\text { Not ZLD, seawater desalination, } \\
\text { energy from renewables, cost } \\
\text { projected to year } 2030 \text {. }\end{array}$ & [34] \\
\hline $\begin{array}{l}\text { UF-NF-MSF- } \\
\text { crystallization system }\end{array}$ & 0.71 & ZLD, seawater desalination. & [19] \\
\hline $\begin{array}{l}\text { UF-NF-RO-MSF- } \\
\text { crystallization system }\end{array}$ & 0.43 & ZLD, seawater desalination. & [19] \\
\hline $\begin{array}{l}\text { Evaporative pond } \\
\text { (lined) }\end{array}$ & 7.28 & $\begin{array}{l}\text { ZLD, shale gas hydraulic fracturing } \\
\text { water desalination. }\end{array}$ & [34] \\
\hline This study (Scenario A) & 4.58 & $\begin{array}{l}\text { ZLD, hypersaline } \\
\text { desalination. }\end{array}$ & NA \\
\hline This study (Scenario B) & 7.80 & $\begin{array}{l}\text { ZLD, hypersaline brine } \\
\text { desalination, with } \mathrm{CO}_{2} \text { capture. }\end{array}$ & NA \\
\hline
\end{tabular}




\section{List of figures}

Fig. 1. Process flow diagram of the multi-stage SCW desalination of hypersaline water with eonventional chemical precipitation pretreatment and zero liquid discharge.

Fig. 2. Process flow diagram of the multi-stage $\mathrm{SCW}$ desalination of hypersaline water with $\mathrm{CO}_{2}$ sequestration and zero liquid discharge.

Fig. 3. Aspen Plus ${ }^{\circledR}$ process flowsheet for Scenario A.

Fig. 4. Aspen Plus ${ }^{\circledR}$ process flowsheet for Scenario B.

Fig. 5. Comparison of annual operating cost in $\mathrm{M} \$$ and mineral product credits for Scenario A and $\mathrm{B}$. 
Figure 1

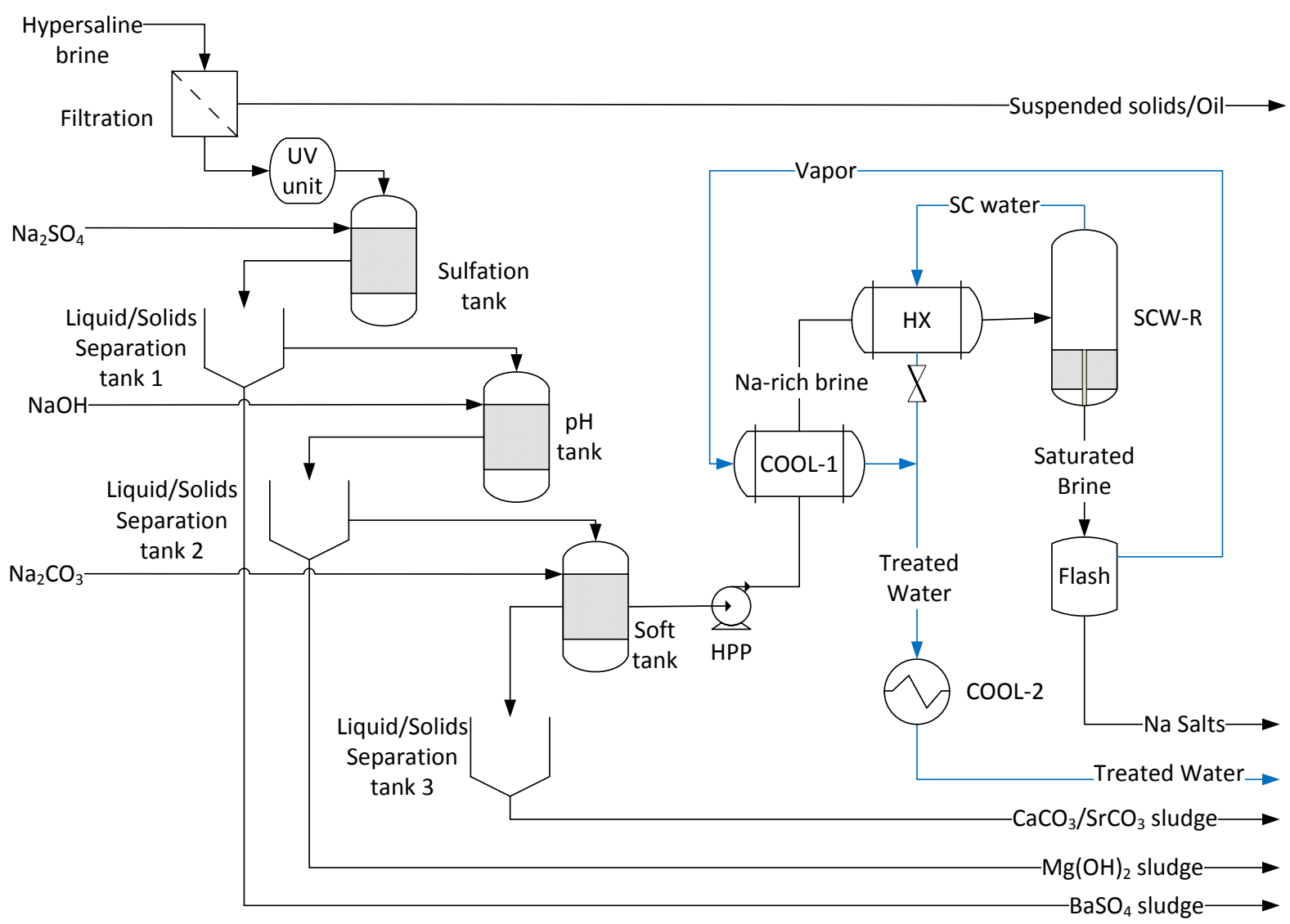


Figure 2

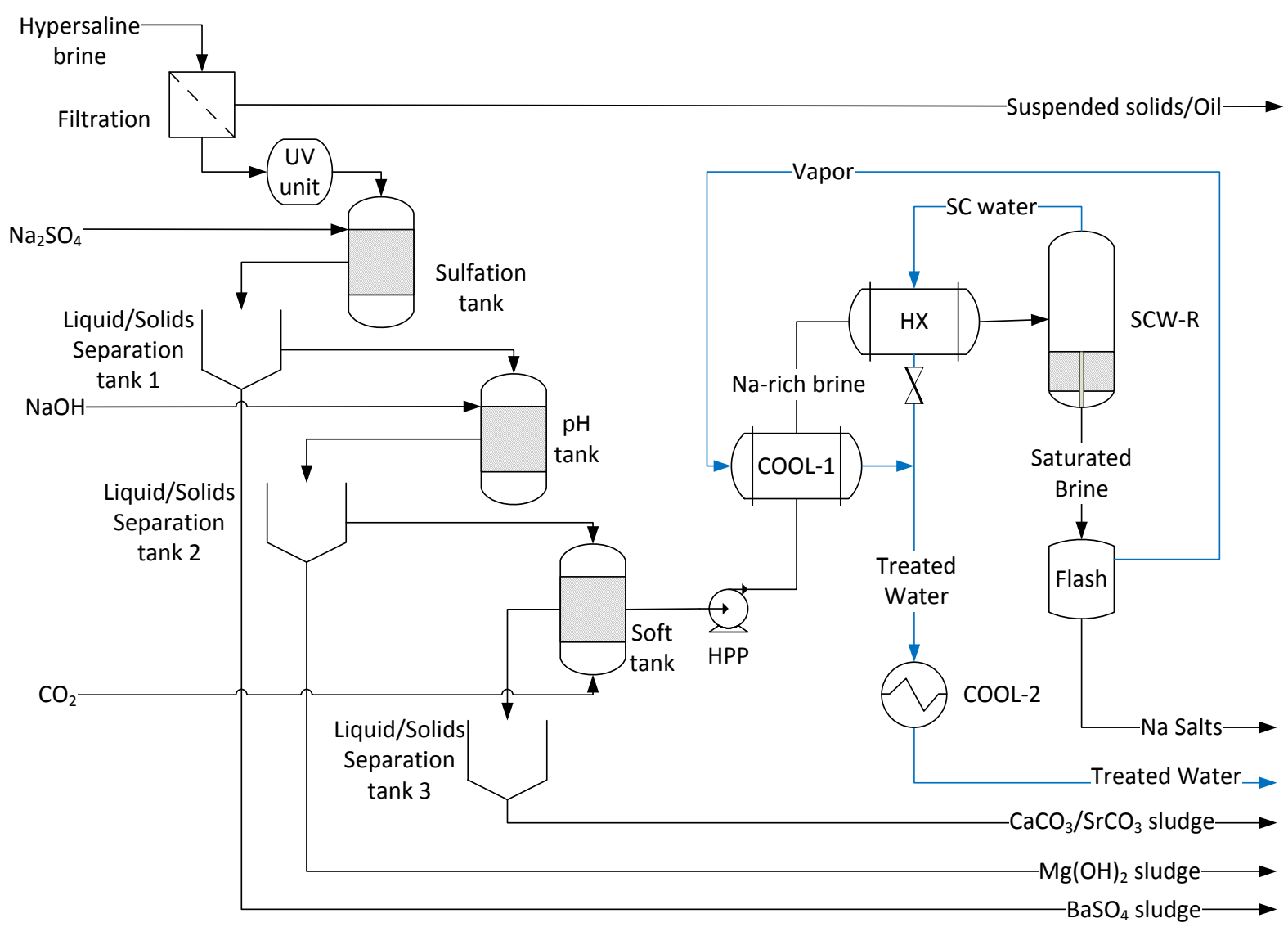


Figure 3

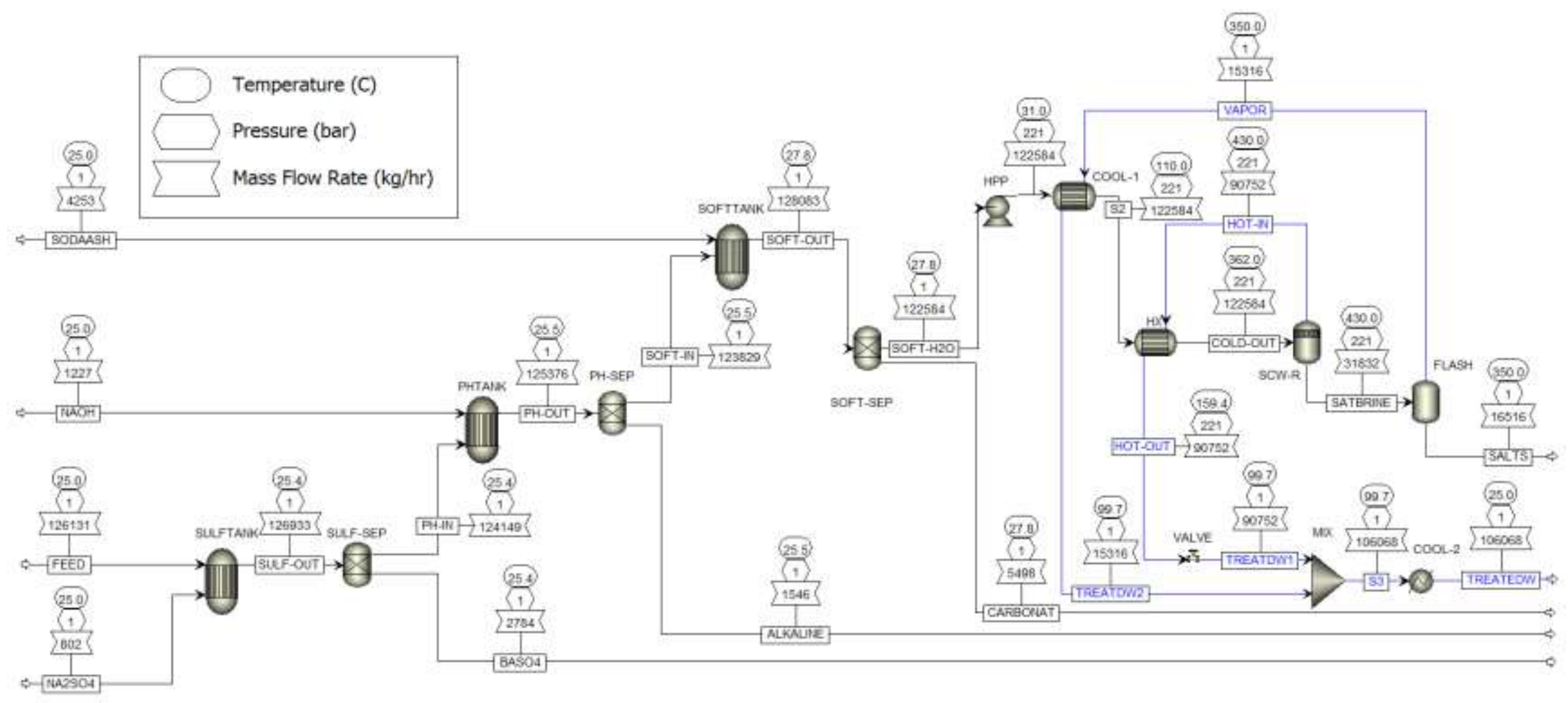


Figure 4

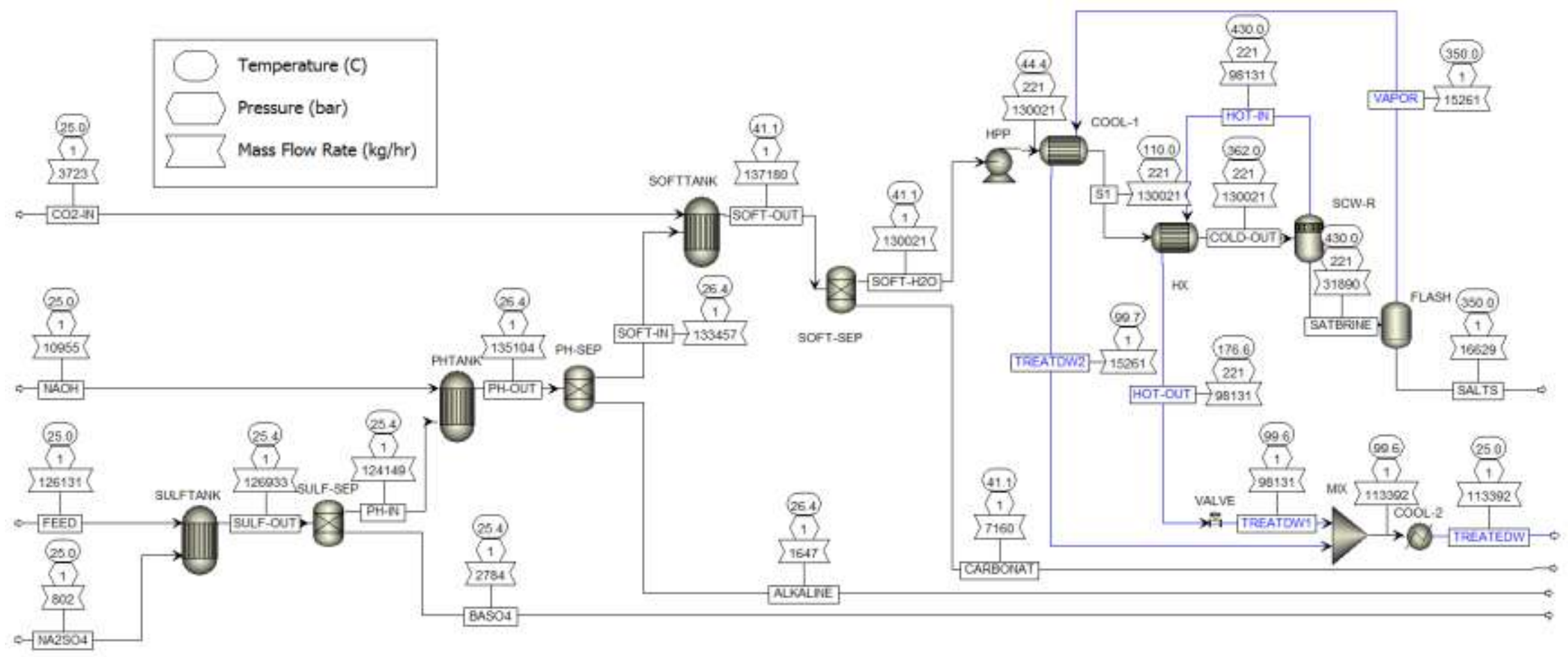


Figure 5

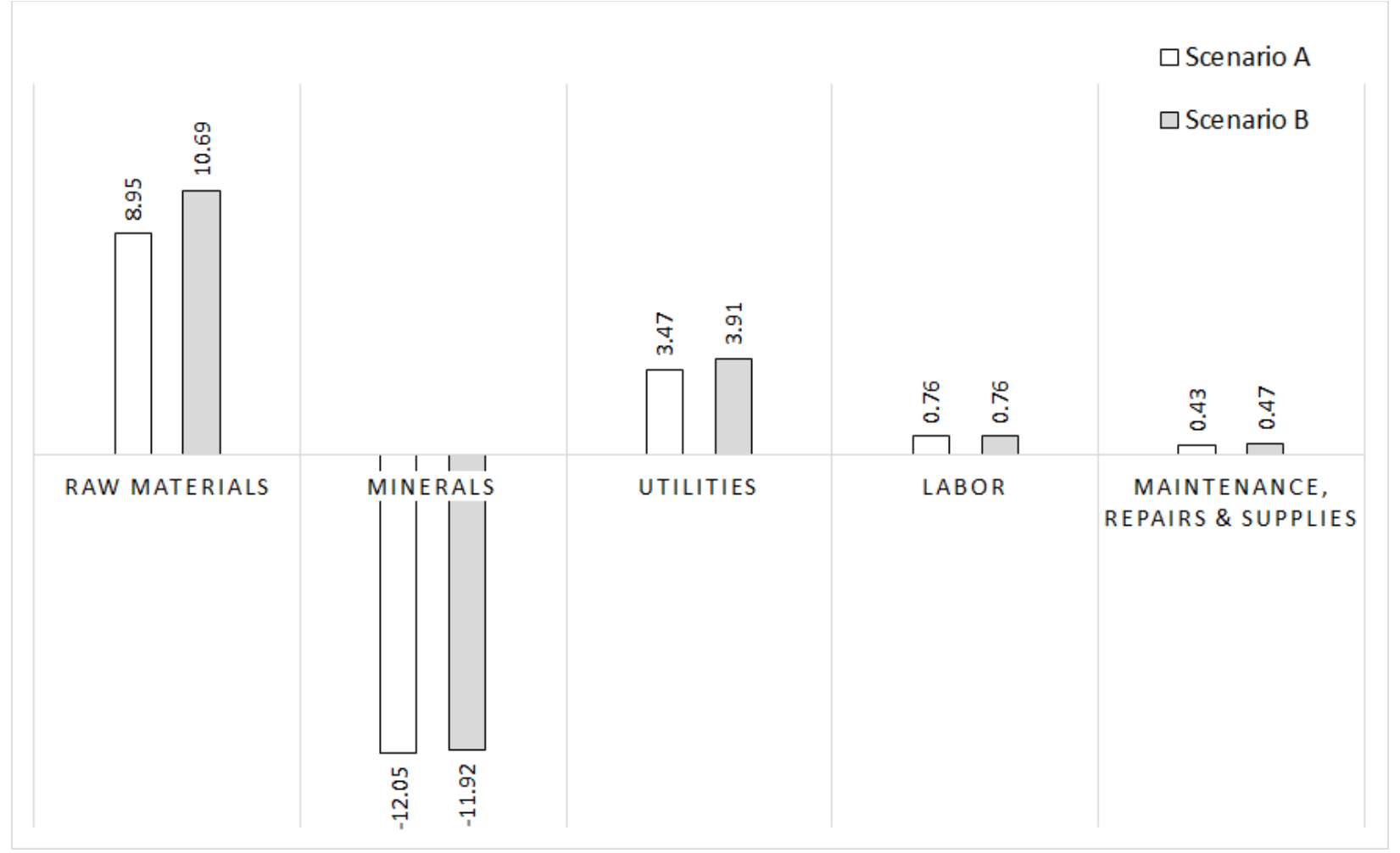


Graphical abstract

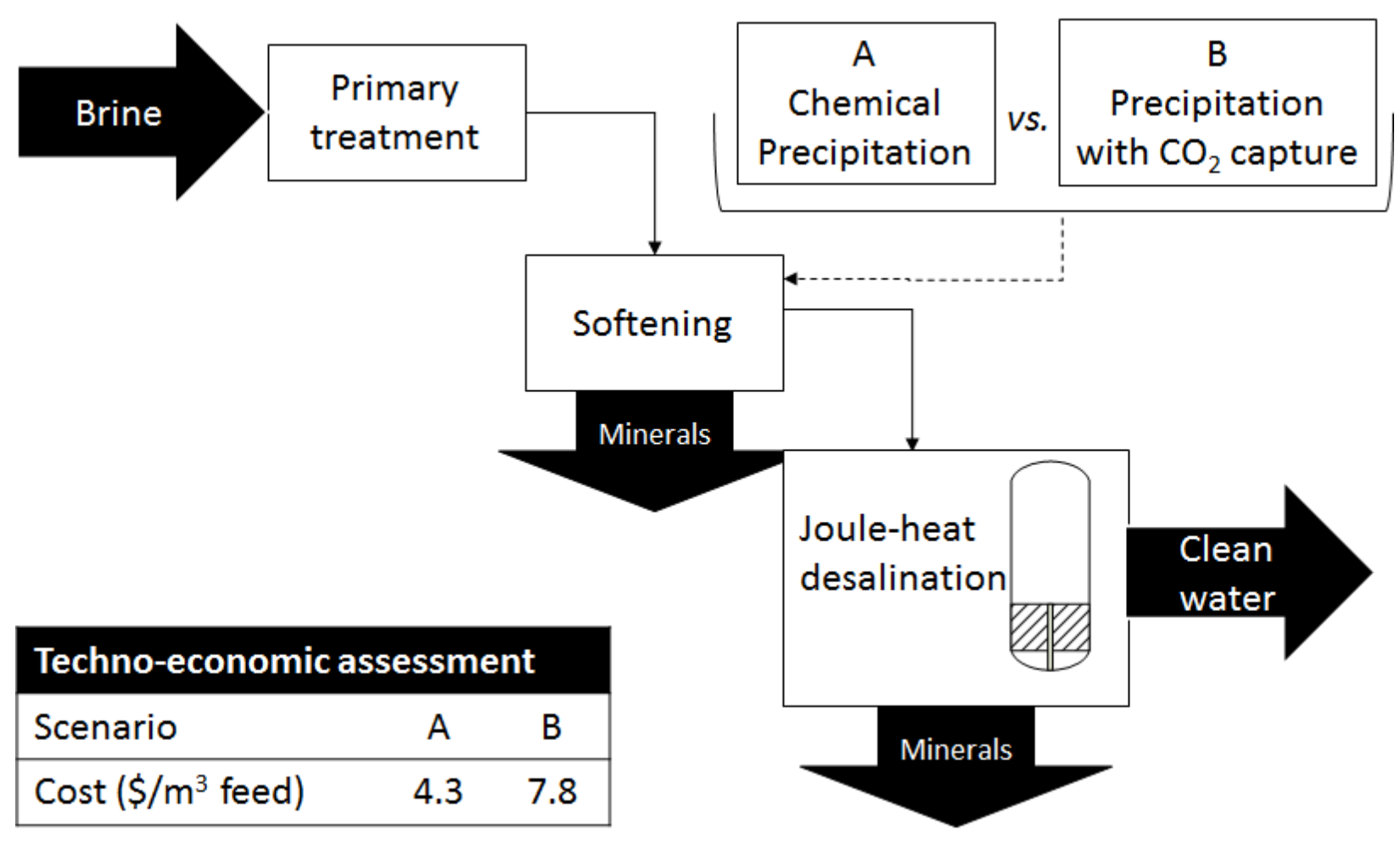

